\title{
Protozoa, Protista, Protoctista: What's in a Name?
}

\author{
LYNN J. ROTHSCHILD
}

Solar System Exploration Branch

MailStop 239-12, NASA-Ames Research Center

Moffett Field, California 94035

A rose may still smell like a rose, but Juliet missed the point. The utility of taxonomic nomenclature lies in the wealth of biological information that it conveys. This biological information is based on relatedness, and in the post-Darwinian era "relatedness" is usually meant in the genealogical sense. However, the fascination with nomenclature goes beyond this, for nomenclature is tempered by a curious amalgamation of pragmatism, priority, prejudice, sociology, and occasionally even humor.

The division between the plant and animal kingdoms would appear to be the most basic taxonomic division. Yet, early workers realized the difficulties associated with classifying organisms that had characteristics of plants as well as animals, such as mobile photosynthetic organisms, and attached or otherwise sessile carnivores. Aristotle had conveyed this sense of taxonomic futility by pointing out that "in the sea, there are certain objects concerning which one would be at a loss to determine whether they be animal or vegetable" (Aristotle 1941:635). With the discovery of microbes, the class of taxonomically ambiguous organisms broadened. Still, taxonomists seemed more comfortable making what some admitted were arbitrary taxonomic decisions rather than challenging the plant/animal dichotomy. Then, within a decade, five workers from both sides of the Atlantic proposed the erection of another kingdom: Richard Owen $(1859,1860,1861)$ designated it the Protozoa, John Hogg (1860) designated it the Regnum Primigenum (Protoctista), Thomas B. Wilson and John Cassin (1863) designated it the Primalia, and. Ernst Haeckel (1866) designated it the Protista. It is only within the last twenty years, however, that the use of a separate kingdom has been widely adopted. This paper focuses on the uneasy taxonomic and phylogenetic position of the unicellular eukaryotes with respect to the animal and plant kingdoms. The emphasis will be on these early proposals for a separate kingdom and the responses they elicited. 
The secondary, but equally fascinating, theme will be the influence of evolutionary theory on classification. Prior to 1859 , classification was an attempt to reveal the "Natural System," a system based either on resemblance or on the underlying plan of the Creator. Charles Darwin, however, argued that the Natural System was to be based on descent (Darwin 1859, chap. 8). Because they arose at this critical period in the history of taxonomy, the nineteenth-century proposals also constitute a case study for the early impact of Darwinian theory on taxonomy.

\section{THE BIRTH OF A DILEMMA}

When Mr. Henry Oldenburg, the first Secretary of the Royal Society, received a letter from Antony van Leeuwenhoek of Delft dated September 7, 1674, he found in it a description of the microscopic life of a nearby lake. Van Leeuwenhoek had "found, floating therein ... very many little animalcules." As C. Clifford Dobell pointed out, "It can hardly be doubted that some, at least, of these animalcules were Protozoa" (Dobell 1932:110). In van Leeuwenhoek's 17 1/2-folio-page letter of October 9, 1676, to the Royal Society, the first detailed account of these "animalcules," or "little animals," appeared. It is likely that included among the animalcules were rotifers and bacteria, as well as pigmented and nonpigmented unicellular eukaryotes (Dobell 1932). When faced with mobile photosynthetic forms, van Leeuwenhoek assigned them to the animals, motility apparently taking precedence over pigmentation. This rationale seems to have been followed by John Harris in his 1696 description of Euglena viridis (Cole 1926), and by the great Swedish taxonomist, Carl Linnaeus. Interestingly, in the 1758 (10th) edition of Systema Naturae, Linnaeus placed most known unicellular eukaryotes in the class Vermes, but in its last order, the Zoophyta. Note the equivocal nature of the ordinal name.

During the latter half of the eighteenth century a new term was introduced. The "Infusion animals" of Martin Ledermüller, or the (latinized) "Infusoria" of Heinrich August Wrisberg, made their debuts in the early 1760 s to describe microscopic organisms that appeared in infusions (Cole 1926: 17). The term "Infusoria" quickly gained prominence when the great Danish biologist Otto Frederik Müller (1730-1784) - known as the "Danish Linnaeus" by some of his contemporaries (with the notable exception of Linnaeus himself) - used it in his posthumous publication of 1786. As might be expected from its derivation, the Infusoria of Müller embraced a taxonomically motley collection of small 
organisms, including unicellular eukaryotes, bacteria, vinegar worms, planaria, cercaria (trematode) larvae, rotifers, "and other odds and ends of animals, provided that they were sufficiently small" (Cole 1926:18). Müller recognized the "Infusoria" as a class of worms, and even the title of his work, Animalcula Infusoria fluviatilla et marina, clearly indicates that he intended his Infusoria to be considered animals. What is perhaps more difficult to understand is Müller's inclusion of the "diatoms" (diatoms sensu lato ${ }^{2}$ and desmids) as animals. Still, it is clear that in Müller's work pigmented forms, and some without mobility such as the desmids, were once again placed among the animals.

In 1807 Jean Baptiste Lamarck recognized the Infusoria as Class I of the Animal Kingdom (Lamarck 1984). Although he realized that they shared some similarities with plants, such as living "entirely by absorption" (1984:135), it was their motility that was again the deciding factor. Lamarck's nemesis, Georges Cuvier, placed the "Infusoires" (along with the sponges, coelenterates, and rotifers) in the Zoophyta, in the animal embranchement Radiata (Agassiz 1857:170).

As Edward A. Minchin explained, "the name Protozoa was first used ... as an equivalent of the German word Urthiere, meaning animals of a primitive or archaic type" (1912:2). The word is derived from the Greek words "proto," meaning "first," and "zoon," meaning "animal." The invention of this evocative term is commonly credited to Georg A. Goldfuss: in his 1817 book, Ueber die Entwicklungsstufen des Thieres ("A work of great rarity," according to Dobell 1932:407), the name "Protozoa" is said to occur in a diagram at the end, as well as in the German

1. Like van Leeuwenhoek's and Harris's Euglena viridis, the diatoms are pigmented, but they tend to be of a brownish rather than a greenish hue owing to the presence of chlorophylls $a$ and $c$, and the secondary pigment fucoxanthin. They have a rigid, siliceous cell wall, and if they move at all, it is by a comparatively slow gliding motion. It should be noted that the sperm of the centric diatoms are, like the euglenoids, flagellated - but, as they would have been seen only rarely and their diatomaceous origin is not evident from gross morphology, I think it unlikely that these workers would have associated anything but a gliding motion to diatoms. The desmids are immobile, unicellular green algae recognizable by being "plant"-green cells composed of two identical hemicells. The diatoms and desmids were classified as "diatoms" prior to the 1833 monograph of Friedrich Traugott Kützing (1807-1893). In this monograph Kützing pointed out the differences between diatoms and desmids, and proposed that the groups be separated.

2. An attempt has been made throughout this paper to use either the terminology of the author under discussion or widely recognized common names. A preferable terminology for unicellular eukaryotes utilizing the suffix "-protista" is discussed in the concluding section. 
form (Protozoen) in the text (Dobell 1932:407). Goldfuss included in his Protozoa the Infusoria, Lithozoa, Phytozoa, and Medusae (Dobell, 1932: 378), and thus included unicellular organisms, sponges, coelenterates, rotifers, and bryozoans (Hyman 1940:44).

The cell theory, promulgated by Schleiden and Schwann in the late $1830 \mathrm{~s}$, profoundly affected subsequent definitions of "Protozoa." In applying the cell theory to the Protozoa of Goldfuss, Carl Theodor Ernst von Siebold (1804-1885), in his 1845 Lehrbuch der vergleichenden Anatomie der wirbellosen Thiere, restricted the Protozoa to unicellular "animals." Thus, in Siebold and Hermann Friedrich Stannius's 1848 text on comparative anatomy - one of the most important systematic reforms since the work of Cuvier - the Protozoa were considered the invertebrates with the lowest organization, and were defined as "Animals in which the different systems of organs are not distinctly separated, and whose irregular form and simple organization is reducible to the type of a cell" (Siebold and Stannius 1854:15). Interestingly, Siebold and Stannius's second group was the Zoophyta, which included the polyps, acalephae, and echinoderms. It would seem that the "phyta" is used here to indicate radial symmetry, a morphology closer to "plants" (including, at that time, fungi) than to other animals.

\section{TIME FOR ANOTHER KINGDOM?}

From a modern perspective, a large part of the futility in assigning unicellular eukaryotes to either the plant or the animal kingdom was due to the presence of forms that are arguably unicellular plants or animals. In addition, there are photosynthetic forms that, pigmentation notwithstanding, are clearly related to nonpigmented forms. Friedrich Kützing, in his 1844 publication "Ueber die Verwandlung der Infusorien in niedere Algenformen" ("On the Change of Infusoria into Lower Forms of Algae"), claimed that "only in the higher organic world is it possible to distinguish at opposite poles animal and plant life, and that these contrasting features do not exist for many lower forms of life" (in Siebold 1845:295). Among Kützing's "lower" and presumably equivocal forms of life were the Infusoria. Perhaps in response, three years later Siebold spent two pages of his Comparative Anatomy defining the boundaries between the plant and animal kingdoms with respect to unicellular forms. Furthermore, Siebold cited his own paper of 1844 in which he had "attempted to show that this confusion between the two kingdoms does not exist" 
(Siebold and Stannius 1854:21). A decade later five workers disagreed to such an extent with views such as Siebold's that they proposed a radical new solution: the erection of another kingdom of nature.

The biography that appeared in the most recent edition of the Encyclopaedia Britannica states that Sir Richard Owen (18041892) was a "British anatomist and paleontologist who is chiefly remembered for his contributions to the study of fossil animals" (de Beer 1985). Ironically, what is not mentioned is that beginning in 1857, Owen delivered a series of lecture courses on paleontology at the Royal School of Mines (Williams 1971) that were published in three works under the title "Palaeontology," the first of which appeared in the 8th edition of the Encyclopaedia Britannica (Owen 1859). This eighty-six-page entry is primarily a catalog of fossils prefaced by a short, conceptual introduction at the conclusion of which Owen attempted to define three deceptively simple terms: "organism," "animal," and "plant."

Organisms, or living things, are those which possess such an internal cellular or cellulovascular structure as can receive fluid matter from without, alter its nature, and add it to the alterative structure. Such fluid matter is called "nutritive," and the actions which make it so are called "assimilation" and "intus-susception." These actions are called "vital," because, as long as they are continued, the "organism" is said "to live." When the organism can also move, receive the nutritive matter by a mouth into a stomach, inhale oxygen and exhale carbonic acid, develop tissues the proximate principles of which are quaternary compounds of carbon, hydrogen, oxygen, and nitrogen, it is called an "animal." When the organism is rooted, has no mouth or stomach, exhales oxygen, has tissues composed of "cellulose" or of binary or ternary compounds, it is called a "plant."

There is nothing extraordinary about the passage for this discussion. What is startlingly novel is what follows:

But the two divisions of organisms called "plants" and "animals" are specialized members of the great natural group of living things, and there are numerous organisms, mostly of minute size and retaining the form of nucleated cells, which manifest the common organic characters, but without the distinctive superadditions of true plants or animals. Such organisms are called 
"Protozoa," and include the sponges or Amorphozoa, the Foraminifera or Rhizopods, the Polycystineae, ${ }^{3}$ the Diatomaceae, Desmidiae, and most of the so-called Polygastria of Ehrenberg, or infusorial animalcules of older authors. (Owen 1859:92)

Thus, Owen had delineated three divisions of life: protozoa, animals, and plants (see Table 1).

The following year "Palaeontology" appeared in book form, and it went through two editions in as many years. Adrian Desmond states that "the Athenaeum greeted it with a yawn," perhaps because, while the catalog was factually accurate and became a standard reference still in use a generation later, the press was looking for something else (Desmond 1982:82). The publication date of the first edition of Palaeontology was April 1860 - only four months after the publication of The Origin of Species. Some had hoped that it would provide a refutation of the Origin, which it did not. ${ }^{4}$ Still, in it are found the developing ideas of Owen regarding the third kingdom that he had erected. The relevant passage in the first edition of Palaeontology is virtually identical to that of the Encyclopaedia Britannica article, with the exception of the addition of a parasitic group, the gregarines, to the list of "Protozoan" groups. Finally, in the second edition Owen gave a clue as to why he chose the term "Protozoa":

... there are numerous beings, mostly of minute size and retain-

Table 1. Summary of the taxonomies erected by Owen, Hogg, Wilson and Cassin, and Haeckel.

\begin{tabular}{llll}
\hline Owen $(1859,1860,1861)$ & Hogg $(1860)$ & Wilson and Cassin (1863) & Haeckel (1866) \\
protozoa & mineral & Primalia & Plantae \\
amorphozoa & vegetable & Algae & Protista \\
plants & animal & Lichenes & Animalia \\
animals & primigenal & Fungi & \\
& protoctista & Spongiae & \\
& protophyta & Conjugata & \\
& protozoa & Vegetabilia & \\
& amorphoctista & Animalia &
\end{tabular}

3. The Polycystineae are also known as the Radiolaria. They are a group of shelled amoebae which have been studied by such workers as Ernst Haeckel and T. H. Huxley.

4. In fairness to Owen, it should be mentioned that in April 1860 he did publish a lengthy attack on the Origin of Species in the Edinburgh Review, 111:487-532. However, it was published anonymously. 
ing the form of nucleated cells, which manifest the common organic characters, without the superadditions of truly distinctive plants or animals. Such organisms are called "Acrita,"* and include the Amorphozoa, or sponges, the Rhizopoda, or foraminifers, the Polycystineae, the Diatomaceae, Desmidiae, Gregarinae, and most of the so-called Polygastria of Ehrenberg, or infusorial animalcules of older authors.

* Acrita: Gr. $a$, expressing want or absence; krino, to separate; signifying a want of distinction or differentiation of tissues and organs. The group has since been called "Protozoa," Gr. protos, first; zoe, life or living thing. (Owen, 1861:4,6)

In light of Owen's paleontological expertise and his discussion of the origins of species that appeared in the first edition of Palaeontology (1860:403-414), he probably used "first" to indicate geological strata, and thus evolutionary time. ${ }^{5}$ His use of $z o e$ was correct etymologically: $z o e$ (or $z o i$ ) can translate as "life." Hence, Owen's term "Protozoa" was perfect to describe his third kingdom - perfect, that is, but for one obvious flaw. As John Hogg, the naturalist and classics scholar, quickly pointed out, "zoa" is most often translated as "animal," and "Protozoa" as "first animals"; thus, to propose "Protozoa" as a term to describe a third, neutral kingdom would have been misleading conceptually, and just plain confusing (Hogg 1860). Subsequent authors (e.g., Copeland 1947) did not adopt the term "Protozoa" for these reasons, while Wilson and Cassin (1863) felt that their additional kingdom was too different in membership to allow the use of the same term. Other authors, such as Haeckel, simply did not mention Owen or his kingdom Protozoa. Thus, Owen's scheme seems never to have been adopted. Owen's addition of the term "Acrita" arose in this work without warning, and seems to have vanished from the literature without serious discussion.

During June 1860, two months after the publication of the first edition of Palaeontology, Owen was in Oxford attending the thirtieth meeting of the British Association for the Advancement of Science. This was the meeting made famous by the Saturday showdown in Section $\mathrm{D}$ between Biship Wilberforce (coached by Owen) and T. H. Huxley. The previous Thursday (June 28), Owen and Huxley had put down their respective verbal gauntlets

5. But Owen is not clear about the "mode of operation" of the "continuously operating secondary cause" (1860:403) that explains the changes in taxa in the fossil record. 
following a talk by Professor C. G. B. Daubeny of Oxford. Their sparring concluded the general portion of Section $\mathrm{D}$, and the Botany portion began. Several papers later, the senior secretary for Section D, Dr. E. R. Lankester, read a paper for Mr. John Hogg. ${ }^{6}$ While history has treated the period between Owen and Huxley's altercation on Thursday and the Wilberforce/Huxley insults on Saturday as a period of relative calm filled with noncontroversial talks, it is Hogg's paper that has sparked the debate among protistologists today.

Hogg complained that it is "impossible for man to determine whether a certain minute organism be an animal or a plant" (1860:223), as locomotion had long since ceased to indicate animality, and the staining of starch with iodine had been weakened as a criterion to distinguish vegetability. As a solution, he proposed the erection of an additional ${ }^{7}$ kingdom, the Regnum Primigenum. In essence, the Regnum Primigenum of Hogg and the kingdom Protozoa of Owen were the same, but to Hogg the prejudicial nature of Owen's term "Protozoa" made it unacceptable to describe his fourth kingdom. Likewise, Hogg objected to Owen's similar designation of the sponges as "Amorphozoa" ("amorphous beings," sensu Owen), "for most of the organisms inserted in it are ... sponges, the animality of which still remains in doubt; for many, including ... Agassiz, Von Siebold, Stannius, Van der Hoeven, \&c., maintain their vegetability" (1860:222).

Hogg's Primigenal kingdom contained "all the lower creatures, or the primary organic beings," the Protoctista - which were to contain the Protophyta and Protozoa, "lower or primary beings having more the nature of plants" and "animals," respectively (1860:223). Hogg did not state explicitly whether he intended to include his newly dubbed "Amorphoctista" (sponges) in the Protoctista, although both the report of the Secretary for Section $\mathrm{D}$ and the report that appeared in The Athenaeum leave no doubt that the (renamed) sponges were to join the Protophyta and Protozoa in the Protoctista. According to Hogg, "Protoctista" means "first created beings." However, $\chi \tau \iota \sigma \tau \alpha$ is more often used for "built" rather than "created" in biblical Greek; in either case, one wonders if the implication of a Creator was intentional. The description accompanying the figure of two pyramids representing

6. Report of the Thirtieth Meeting of the British Association for the Advancement of Science, 1861; and the entire paper was published in the October 1860 edition of the Edinburgh New Philosophical Journal (Hogg 1860). An additional account appeared in The Athenaeum, July 7, 1860 (Anonymous 1860).

7. In this case, a fourth kingdom, the first three being the Mineral, Vegetable, and Animal kingdoms of Linnaeus. See Table 1. 
the vegetable and animal kingdoms arising from a protoctistan base states that the ascent up the pyramids represents an ascent to organisms of a more perfect state of existence. In describing Hogg's description of his figure, the Athenaeum report (Anonymous 1860) stated that "the Primigenal Kingdom ... embraces the lower or primary organisms of both the former [animal and plant] kingdoms but which are of a doubtful nature, and can in some instances only be considered as having become blended or mingled together." Again, this does not suggest that the animal and vegetable kingdoms had their evolutionary origins in the Primigenal Kingdom, as perhaps Owen had implied with his Protozoa. So, from the available evidence, Hogg was not erecting the Primigenal Kingdom for genealogical reasons.

In some ways it is not surprising that Hogg entered the additional-kingdom debate. John Hogg (1800-1869) was a Cambridge-educated man of diverse accomplishments who distinguished himself in such fields as classics, law, and natural history. He was elected to many societies, including the Linnean Society in 1823 , and the Royal Society thirteen years later. He published more than forty papers in the field of natural history, spanning the entire taxonomic range. ${ }^{8}$ In 1838 , while a fellow of St. Peter's College, Cambridge, he contributed an abstract to the Philosophical Transactions of the Royal Society on the green color of the sponge Spongilla fluviatilis: attributing the green color to the direct action of sunlight (rather than to what we now know are endosymbiotic algae), he used this character to suggest that $S$. fluviatilis was "nearer allied to the Algae or Fungi, than to any other tribe belonging to the animal kingdom" (1838:72). Thus Hogg had spent many years puzzling over organisms that seemed ambiguous in their taxonomic position.

Still, there are many questions about Hogg's 1860 paper that remain unanswered. Why wasn't he at the presentation of his own paper? If it was due to ill health (he was about age sixty at the time), it was not mentioned in the reports of the meeting. Was Richard Owen, who was both a section vice-president and a prominent figure in Hogg's argument, at Hogg's paper? If so, what were his reactions?

We do know of several nineteenth-century reactions to Hogg's paper. The first was the immediate reaction of the reader, Dr. Lankester, who "could not agree with the author as to the necessity of a fourth kingdom in nature" (Anonymous 1860).

8. Biographical information was obtained from The Dictionary of National Biography (G. G. 1937). 
Another came from two workers in the United States, Dr. Thomas B. Wilson, (1807-1865) and John Cassin (1813-1869). Three years after Hogg's presentation, Wilson and Cassin presented their opinions "On a Third Kingdom of Organized Beings" $\left(1863^{9}\right)$, in which they erected the kingdom Primalia. The authors' collaboration had begun during the late 1840s when Wilson started assembling a large collection of birds and ornithological publications, and Cassin became responsible for its proper arrangement and identification. The resulting publications focused primarily on taxonomic problems and established Cassin as the leading American ornithologist of his day. From this information, it is difficult to guess why these workers should have concerned themselves with a third kingdom, unless it was their general interest in taxonomy.

The most striking philosophical difference between the proposals of Wilson and Cassin and those of Owen and of Hogg is the evolutionary role of the American scientists' third kingdom, the Primalia. As pointed out above (n. 4), although Owen's anonymous 1860 review of the Origin of Species was negative, he was by this time certainly not opposed to the idea of organisms changing through the paleontological record (Owen 1860; MacLeod 1965; Desmond 1982); and yet, he did not make explicit the evolutionary role of his Protozoa. The name of the members of Hogg's additional kingdom, the Protoctista, had a literal creationist derivation. In contrast, Wilson and Cassin, while equivocating on the exact mechanism for change, did postulate an important evolutionary role for the kingdom Primalia, which was to assume the evolutionary position between inorganic matter on the one hand, and the kingdoms Animalia and Vegetabilia on the other.

Wilson and Cassin's Kingdom Primalia (see Table 1) was to contain certain organisms of what we would call a unicellular nature - or, at most, a unicellular aggregation "entirely capable of nutrition and propagation or increase, but without any part of their structure being traceable as vascular in any degree" (1863:117). The kingdom was divided into the subkingdoms Algae, Lichenes, Fungi, Spongiae, and Conjugata. Since the authors considered the Primalia as "containing the whole of the Kingdom Protozoa of Professor Owen" (1863:118-119), one must assume that the "Conjugata" included Owen's rhizopods, Infusoria, and gregarines. They also segregated into this third kingdom several groups that previously had been left among the plants and animals. This taxonomic reassignment had the effect of phylogenetically purify-

9. The Proceedings, however, were not published until 1864. 
ing the plant and animal kingdoms, but it made the third kingdom extremely diverse and therefore highly "unnatural" (Bütschli $1880-82^{10}$ ).

Why did Wilson and Cassin choose the name "Primalia"? First, it reflected their view of this taxon as a "primary division or kingdom." Second, they rejected Owen's term "Protozoa," while "admitting its excellence, and willing to express freely our regret that we do not consider it proper to adopt it as the name of our first kingdom," because it had "been applied originally to a group very different in all particulars" (1863:118). ${ }^{11}$ Third, they rejected Hogg's Regnum Primigenum for the same reason: it was composed of the same groups as Owen's kingdom Protozoa. However, Wilson and Cassin's kingdom Primalia was to suffer the same relegation to taxonomic obscurity as Owen's Protozoa and Hogg's Primigenum.

Unlike the other workers who proposed an additional kingdom, Ernst Haeckel (1834-1919) made significant contributions concerning the biology of unicellular eukaryotes. While studying medicine in Berlin, he came to idolize the distinguished physiologist and comparative anatomist Johannes Müller. Haeckel wished to study under Müller after obtaining his medical degree, but Müller died in 1858. Since 1840, Müller had focused his research on comparative zoology, and at the time of his death he was working on two groups of amoebae, the Radiolaria and Foraminifera. After Müller's death, Haeckel continued Müller's research on the Radiolaria. The resulting monograph, Die Radiolarien (Haeckel 1862), was considered sufficiently distinguished that Jena University founded a chair for him in zoology.

After reading the Origin of Species, Haeckel decided that his future lay in developing Darwinism, a field that he believed would lead to a reform in biology and a science-based world-view. Particularly important to Haeckel was the historical aspect of Darwinism - that is, discerning genealogical lineages. His great serious scientific work, Generelle Morphologie der Organismen (1866), was a massive attempt to synthesize these views. The Generelle Morphologie was not as well received as Haeckel had hoped; in fact, it was heavily criticized by his colleagues (Smit

10. See below for more on Bütschli's critique of proposals for alternate kingdoms.

11. This points out an interesting taxonomic dilemma: does one slavishly follow the first published definition of a group, or current usage, or a proposed definitional change? It is illustrative to note the changing membership in the animal and plant kingdoms over the millennia, many examples of which are provided in this paper. 
1967) and still has not been translated into English. Yet, today this work is popularly regarded among protistologists as the founding work in their amalgamated discipline. What was so special about Haeckel's additional kingdom?

Haeckel's work on the Radiolaria provided him with a detailed knowledge and appreciation of unicellular organisms so that, as had his predecessors, he recognized the difficulties in assigning many groups to either the plant or the animal kingdom. Additionally, his primary interest was in the elucidation of "natural" (genealogical, or, to use Haeckel's own word, "phylogenetic") relationships. As a consequence, he must have felt the need to set up a scheme for these organisms that would reflect their natural relationships. He admitted that unfortunately the knowledge available on unicellular organisms was scarce, especially in comparison to that available for animals and plants. Thus, his natural system for his additional kingdom, the kingdom Protista (see Table 1), or "the ones who came first in time,"12 would have to be tentative. In fact, Haeckel doubted that the Protista as a whole were monophyletic, although he thought that each subgroup was so (1892:56), and he allowed for the possibility that they were still emerging.

The composition of Haeckel's first kingdom Protista (Haeckel 1866) can be extracted from his figure showing the relationship of the kingdom Protista to the plants and animals (see Fig. 1) which is thought to be the first phylogenetic tree published (Dobzhansky et al., 1977:242). Included in the Protista were the Moneres (bacteria, but excluding the blue-green algae or cyanobacteria), Protoplasta (naked and some testate amoebae, as well as gregarines), Flagellata (e.g., Euglena and Volvox, and some dinoflagellates such as Peridinium), Diatomeae, Myxomycetes (slime molds), Myxocystoda, Rhizopoda (including the Radiolaria), and the Spongiae. Equally interesting are the groups that Haeckel excluded. While Wilson and Cassin placed the lichens, fungi, and "higher algae" (e.g., red, brown, and green algae) in the kingdom Primalia, Haeckel placed these groups among the Plantae. Meanwhile, he placed the "Infusoria," a term which by this time was virtually synonmous with the ciliates of today, among the Animalia as an offshoot of the branch leading to the Articulata (e.g., the arthropods, worms, and rotifers). More important, as his figure

12. An alternate translation of "protista" is "the ones who come first in priority." But this latter translation is unlikely to be the one Haeckel intended because of the evolutionary role that he assigned to the Protista. 


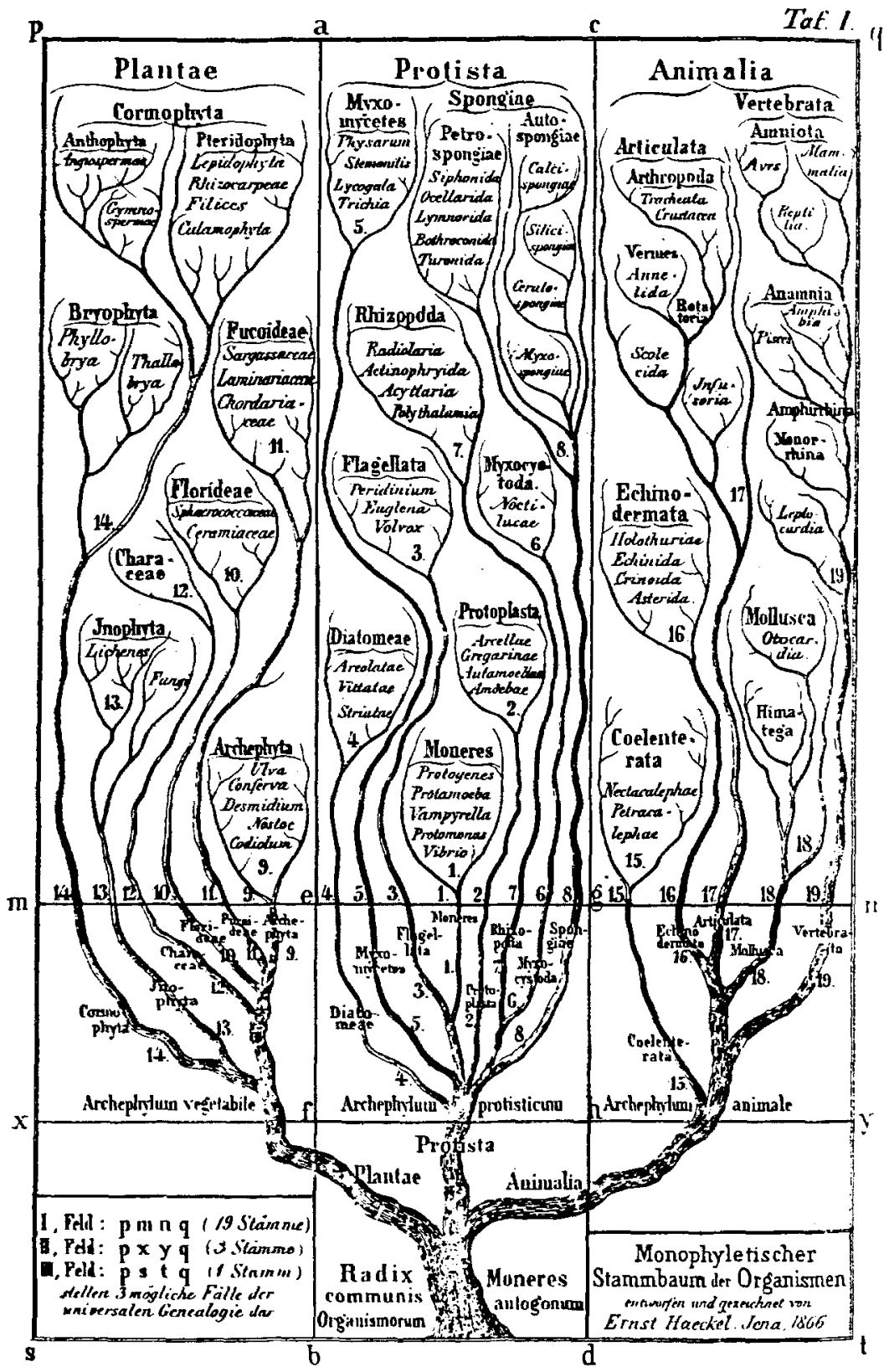

Figure 1. Reproduction of Plate 1 from the Generelle Morphologie (Hackel 1866). Note the position of the protistan branch in relation to that of the Animalia and Plantae, and the taxa included in these three kingdoms. 
implies and he later articulated (1892:49), the vast majority of Protista are shown to bear no phylogenetic relationship to either plants or animals.

Twelve years after the Generelle Morphologie, Haeckel published Das Protistenreich (1878). Here he reiterated his views on the evolutionary significance of the Protista, stating that "for a deeper understanding of our present development and the view of the world that is built upon it, there can be few branches of natural science of such importance as the natural history of the lower forms of life, the so-called Protista" (Haeckel 1878:1). The protistan kingdom presented in this work is different from that of 1866: the sponges had been removed in 1869 because they exhibit larval stages, which suggested true animality (Cole 1926:33), and thus the ciliates (as Infusoria), which do not have larval stages, had to be moved from the Animalia to the Protista. The new kingdom Protista of 1878 thus contained the following ten taxa: the Monera, Lobosa (Amoebina), Gregarinae, Flagellata (including many pigmented forms), Catallacta (e.g., Synura), Ciliata, Acinetae (Suctoria, a group of ciliates), Labyrinthuleae (a peculiar group with amoeboid cells that form an ectoplasmic network), Bacillariae (the diatoms), Fungi, Myxomycetes, Thalomorpha (Rhizopoda), Heliozoa ("sun animalcules"), and the Radiolaria.

In summary, the proposals for an additional kingdom put forward by Owen, Hogg, Wilson and Cassin, and Haeckel vary in several important respects: composition, associated nomenclature, and evolutionary significance. Owen's Protozoa, or "first living things," was to include a variety of unicellular taxa and sponges, but it was rejected by Hogg and by Wilson and Cassin because of nomenclatural ambiguity and priority. Hogg's Regnum Primigenum was similar in composition to Owen's Protozoa, but with different associated nomenclature; of particular interest is the nomenclature describing the members of the Regnum Primigenum, the Protoctista or "first created beings." The kingdom Primalia, or "primary division," of Wilson and Cassin included Owen's and Hogg's kingdoms, as well as the (multicellular) algae, lichens, and fungi, and was to be the evolutionary link between inorganic matter and the animal and vegetable kingdoms. Haeckel's kingdom Protista, "the ones who came first," was, like Wilson and Cassin's Primalia, to represent the first organisms in evolutionary time. Initially, the Protista included only unicellular forms and sponges (like both Owen's and Hogg's additional kingdoms) but excluded the ciliates. With the enunciation of the gastraea theory, Haeckel forced himself into moving the Infusoria (ciliates) from the Animalia to the Protista in exchange for the sponges. 


\section{EARLY RESPONSES TO THE FLEDGLING KINGDOM}

With this background, it is curious that it is the kingdom Protista of Haeckel that has always been the most widely adopted, even if the composition of this group has remained a matter for dispute. There are several possible explanations. While the other proposals were buried either in society proceedings or in works of interest primarily to those not concerned with unicellular organisms, Haeckel relentlessly popularized his "Protistenreich" in books and, presumably, his many lectures. In addition, he did not mention the proposals of Owen, Hogg, and Wilson and Cassin. Perhaps Owen was ignored because his reputation declined during the $1860 \mathrm{~s}$, and Hogg because he had been out-of-date for years (he did not even receive the customary obituary in the Proceedings of the Royal Society). ${ }^{13}$ In any case, by not mentioning his predecessors, Haeckel helped to make this literature invisible.

Still, adoption of the kingdom Protista was neither immediate nor universal. The Englishman W. Saville Kent (1845-1908), student of the "lower" metazoa, sponges, and unicellular eukaryotes, provided one of the early critiques of Haeckel's (already severaltimes-reincarnated) Protista. While admitting the difficulties involved in dividing unicellular organisms between the animals and vegetables, he disapproved of Haeckel's solution:

This attempt to cut the Gordian knot by the interpellation of a third and intermediate kingdom, is by no means happy. Even if this latter possessed in itself the elements of stability, the difficulty would be in no ways lessened, but simply augmented, as there would be now two lines of demarcation, one between the Protista and vegetable forms, and the other between the Protista and the animal series, to be defined in place of the pre-existing single one. The Protista, however, as a group separate from both the animal and vegetable kingdoms, has no real existence, there not being, with the exception of the Diatomaceae, a single family or generic type included in Haeckel's tabular view of his new kingdom that cannot with tolerable, if not absolute certainty, be referred to the former of these two sections. (Kent, 1880-81:44)

An even more important critique of Haeckel was that of Kent's contemporary, Otto Bütschli. Bütschli (1848-1920), Professor of Zoology at the University of Heidelberg, overshadowed many of

13. I would like to thank Fred Churchill for these suggestions. 
his contemporaries, including Kent (see Corliss 1978 for brief biographies of both Kent and Bütschli). The man whom Dobell dubbed the "architect of protozoology" produced several massive tomes, totaling 2035 pages and covering the classification of all protozoa. These works were published between 1880 and 1889 in volume I of Heinrich Georg Bronn's Klassen und Ordnung des Thier-Reichs, the posthumous realization of Bronn's efforts to produce a systematic work covering the entire animal kingdom including fossil and recent forms. In the prefatory pages to his first contribution (1880-82), Bütschli presented a lengthy and vehement critique of the attempts to erect an additional kingdom. This critique centered around three taxonomic criteria: morphology, physiology and genealogy. While Bütschli agreed that genealogy must provide the ultimate basis for classification, his difference with Haeckel seems to have been based on how best to determine genealogy. Both admitted that relationships are hard to discern among these organisms, ${ }^{14}$ yet Bütschli claimed (perhaps erroneously - see Haeckel 1892: chap. 18) that Haeckel opted for a physiological criterion while he (Bütschli) insisted that morphological distinctions best reflected genealogical relationships. For this reason Bütschli was particularly adamant about not including fungi in an additional kingdom, for their unique higher organization would make the Protista impossible to define morphologically. Of course one cannot help but note that assigning the fungi and other (sometimes) Haeckelian Protista to the plant and animal kingdoms greatly weakens the morphological coherence of these groups. Yet Bütschli said that since the two "higher" kingdoms were already artificial, increasing their artificiality hardly seemed to matter. Furthermore, if Haeckel's Protista were polyphyletic (which Haeckel himself admitted was probably the case), why erect another artificial kingdom?

By 1880 Haeckel had divided the Protista into several groups. The term "Protozoa" was resurrected to refer to those Protista that were ancestral to the animals, and "Protophyta" was similarly applied to the ancestors of the plants (Haeckel 1892). Protista that were not ancestral to either group were put in the "Protista Neutralia." But, Bütschli asked, how can these divisions be determined? For example, why did Haeckel place the rhizopods in the neutral Protista while the amoebae and gregarines were

14. How Haeckel and Bütschli would have loved to know that current advances in cell and molecular biology suggest that the taxonomic answers they sought are obtainable, although not quite as easily as some workers would have one believe (e.g., see Rothschild et al. 1986 for a critique of rRNA sequence comparisons in taxonomy). 
designated as Protozoa? To Bütschli, this seemed an "insoluble riddle," and so "it would appear to be better to leave the old kingdoms and to distribute one-celled creatures between the same as best we can, just as it has been done for a long time" 1880 82:ix).

Herbert F. Copeland argued that Bütschli's criticisms, presented in an authoritative volume, were "apparently responsible for the subsequent consensus of opinion that no additional kingdom is to be recognized" (1947:341). In addition, Bütschli enumerated Haeckel's critics but did not even list his supporters because he claimed that since they had not contributed anything new, it was not worth citing them (Bütschli 1880-82). These factors may have been important in delaying recognition of the kingdom Protista, for the acceptance of a taxonomic scheme is, to some extent, a political process, where both public support from "authorities" in a visible format and peer pressure nudge others into acceptance. This aspect of the recognition of a taxonomic scheme is well illustrated with the Protista. It may also be from Bütschli, through Copeland (1947), that several errors have been perpetuated in some of the twentieth-century literature: both workers cite the publication date of Hogg's paper as 1861 rather than 1860, and both cite Hogg as having erected the kingdom Protoctista rather than the Regnum Primigenum containing the Protoctista.

\section{THE TWENTIETH-CENTURY PROTISTAN REVIVAL}

The term "Protista" was not completely moribund between Kent's and Bütschli's work of the 1880s and the more recent protistan revival. In 1902 Max Hartmann, a former student of Richard Hertwig, who in turn had been a student of Haeckel's, founded the Archiv für Protistenkunde. According to Raymond C. Moore (1954), it was through the establishment of this journal (along with references made in textbooks) that the term "Protista" first gained popularity. One of the strongest supporters of the protistan concept was an Englishman, C. Clifford Dobell (18861949), who spent a brief time in Munich with Richard Hertwig. Partially in support of the protistan concept, Dobell published an important work, "The Principles of Protistology," in Archiv für Protistenkunde (Dobell 1911). ${ }^{15}$

15. This remains one of my favorite articles, well worth reading if only for the still-appropriate demolition of this protistologist's pet peeve: the use of the expressions "lower" and "higher" organisms. I would like to thank John Corliss for bringing this article to my attention several years ago. 
Even with Dobell's staunch support for the "Protista," the concept and the term continued to receive mixed reactions. Dobell's countryman Edward A. Minchin (1866-1915) objected to the Protista because its boundaries cut across the animal and plant lineages, and because by the inclusion of the Bacteria, the Protista became too diverse; nonetheless, in his Introduction to the Study of the Protozoa he defined Protozoa as a type of Protista (Minchin 1912:10). In a more influential text, the Handbook of Protozoology, R. R. Kudo opposed the concept of Protista for reasons similar to those of Kent (e.g., Kudo 1931, 1966). Likewise, in her still-important series, The Invertebrates, Libbie $\mathrm{H}$. Hyman (1888-1969) placed the Protozoa as a phylum in the animal kingdom (Hyman 1940:44) and ignored the protistan proposals.

More than any other investigator, Herbert F. Copeland of Sacramento College kept the protistan concept alive during the period between the work of Dobell and that of Robert $\mathrm{H}$. Whittaker. Copeland became interested in comprehensive taxonomic schemes through his father, the botanist E. B. Copeland (Copeland 1938, 1956:3-4). In 1938 H. F. Copeland published a lengthy consideration of the kingdoms of organisms in which he concluded that the kingdoms Monera (Haeckel) and Protista (Haeckel) should be recognized along with the Plantae (Linnaeus) and Animalia (Linnaeus); here the Protista included the Fungi. Copeland claimed that the two-kingdom system had "persisted for want of a workable substitute," but now in his four-kingdom system he provided a suitable alternative.

Several years later, Copeland presented a continuation of his 1938 paper at the Western Society of Naturalists meeting (Copeland 1947). The purpose of the latter paper was to solve nomenclatural problems, especially where nomenclature and taxonomy had lagged behind evolutionary revelations. While his proposals remained essentially unchanged from his earlier work, he changed the names of two kingdoms. He now believed that he had been in error in using the names "Monera" and "Protista" and was all the more embarrassed because R. Y. Stanier and C. B. van Niel (1941) had used the name "Monera" on his authority. According to Copeland (1947), "Moneres" was not an appropriate term because the presumptive type, Protamoeba, turned out to have been a fragment of an amoeba; clearly, a name typified by an artifact should not be valid. And based on a reading of Bütschli's work in Bronn's Klassen und Ordnung (1880-82), Copeland discarded "Protista," arguing that "Protoctista" was more appropriate because this name was published prior to "Protista." Owen's 
term "Protozoa," while having priority over "Protoctista," was unnacceptable because it had previously been used for a class and a phylum.

In retrospect, the resurrection of "Protoctista" was unfortunate for several reasons. As I have demonstrated above, "Protoctista" was not originally used for the name of a kingdom but to describe the members of the kingdom Primigenum. The derivation of the term has clear antievolutionary overtones, which makes "Protoctista" a peculiarly inappropriate term to resurrect. While "Protoctista" does have priority over "Protista" in some sense, it does not have priority over Owen's "Protozoa." In any case, neither the botanical nor the zoological Code of Nomenclature applies to taxa over the familial level - thus, priority on the kingdom level is strictly a matter of preference and good manners, not taxonomic law. Neither Hogg's Protoctista nor Haeckel's Protista were defined by these workers in a way that is identical with modern usage (whatever that may be), so that this is not a reason to reject "Protista" (see n. 11, above). And furthermore, there is an obvious problem with "Protoctista": it is not at all euphonious (Heywood and Rothschild 1987).

Although Copeland's audience at the Western Society of Naturalists meeting showed some interest in his ideas, he admitted that they failed to win acceptance. In spite of this lack of enthusiasm, he continued to be interested in the classification of unicellular organisms and went on to write The Classification of Lower Organisms, which was not published until 1956. In the interim, and during the period between the publication of Copeland's book and Whittaker's seminal 1969 paper, there was a renewed discussion of the early proposals for an additional kingdom of organisms. A new generation of workers capitalized on fresh biological information to alter old proposals and to suggest new ones. ${ }^{16}$ Like their predecessors, these workers were concerned about erecting a natural system of classification. This time two secondary issues dominated the discussion: (1) the relationship of unicellular creatures with and without nuclei, and (2) questions of nomenclatural priority.

It will be recalled that Haeckel (1866) had first separated the anucleate organisms into a separate taxon, the Moneres, within the kingdom Protista. Bütschli (1880-82) had objected to this because he believed that many of Haeckel's Monera (e.g., Protamoeba) lacked a nucleus solely as an artifact of collection or preservation. By the mid-twentieth century no one doubted that

16. For additional references, see Whittaker (1969). 
there were bona fide anucleate organisms. As techniques in microscopy (and, much later, molecular biology) advanced, it became increasingly obvious that there exists a very profound division between anucleate organisms (now called prokaryotes) and nucleate organisms (eukaryotes). As for priority, although the codes of nomenclature do not extend to taxa above the familial level, taxonomists seem to be quite concerned with this issue. Thus, in the late 1940s there began fresh discussions of the work of Owen, Hogg, Wilson and Cassin, and Haeckel. The interpretation of the first generation of alternate-kingdom workers by their mid-twentieth-century intellectual descendants is of interest to both historian and biologist, for it is these workers who laid the groundwork for the current debates.

In 1948 Werner Rothmaler erected a four-kingdom system comprised of the Anucleobionta (without a nucleus), the Protobionta (unicellular or thallous protista), the Cormobionta (multicellular plants with stomata), and the Gastrobionta (multicellular animals with an alimentary canal). The Protobionta were divided into four phyla on the basis of pigmentation and flagellar structure. Unfortunately, Rothmaler did not state why he was proposing new terminology, nor was he clear as to the evolutionary relationships that his taxa were to demonstrate. His work has not been adopted.

After Rothmaler, the United States became the battleground for the establishment of an additional kingdom. Raymond C. Moore of the University of Kansas became involved in the alternatekingdom issue as editor of the Treatise on Invertebrate Paleontology. Prior to compiling the Treatise, he made the unusual move of publishing an article rationalizing his approach to classification in the Treatise (Moore 1954). As editor, Moore encountered the difficulty of delimiting the Protozoa, and therefore he proposed the adoption of the kingdom Protista. His Protista included two subkingdoms, the anucleate Monera and the nucleate Protoctista. He justified the inclusion of the entire kingdom Protista in a treatise on invertebrates because, as a whole, fossil Protista are in the realm of neither paleobotany nor paleozoology but, because of their evolutionary history, gradate into both. In addition, many workers who call themselves invertebrate paleontologists work primarily on Protista, conodonts, and other such creatures that cannot be definitively included amongst the invertebrates. This practical aspect of the problem was joined by the fact that the name of the Treatise had been determined prior to Moore's decision to recognize and include a kingdom Protista. There are two other interesting points concerning his paper. First, while Hogg (1860) and Haeckel (1866) were cited, the works of Owen 
and of Wilson and Cassin were not. Second, Moore identified the reason for the "tardy recognition of the Protista" as the lack of clear delimitation of the protistan kingdom. In addition, he was less concerned with the scope of Haeckel's original kingdom Protista than with what the concept had come to mean in accepted usage.

The following year Ellsworth Dougherty published a review of the origin of sexuality (Dougherty 1955). Like Moore, Dougherty was not concerned with systematics or the evolution of unicellular organisms per se, but required systematics as a prerequisite to comparative biology..$^{17}$ While Moore agreed that there were good evolutionary reasons for the recognition of the kingdom Protista, Dougherty recognized four major groups (Monera, Protista, Metaphyta, and Metazoa) similar to those of Copeland (1938) "out of convenience," stating that "the boundaries between these groups are arbitrary" (Dougherty 1955:148).

At this point Copeland brought out his grand work on systematics, The Classification of Lower Organisms (1956). The express purpose of this book was to persuade the community of biologists that the accepted primary classification of living things into two kingdoms, plants and animals, should be abandoned; that the kingdoms of plants and animals are to be given definite limits; and that the organisms excluded from them are to be organized as two other kingdoms. Copeland insisted that the names of the additional kingdoms, as fixed by generally accepted principles of nomenclature, were "Mychota" and "Protoctista" (1956:1).

In essence this book was an expansion of Copeland's earlier works $(1938,1947)$, and with the expanded format he was able to discuss more fully what he perceived to be the appropriate methods and purposes of taxonomy. Kent (1880-81), Bütschli (1880-82), Kudo (1931), and others had argued that the erection of an additional kingdom was not justified if the boundaries could not be clearly delimited and in a way that did not rely on negative characters. Copeland believed that he had answered these criticisms. In addition, he rejected Rothmaler's suggestion of including the green algae in the (in Rothmaler's terminology) Protobionta (Rothmaler 1948): because green algae "represent the undoubted evolutionary origin of the higher plants" (Copeland 1956:38), a natural classification should place these organisms with the plants. ${ }^{18}$

17. This is an extremely important justification for systematics that experimental biologists have a tendency to forget.

18. Note that the taxonomic recognition of the genealogical relationship between green algae (chloroprotista) and the plants has also been suggested by 
Support for Copeland's four-kingdom system came from several quarters. In 1963 Richard E. Blackwelder, at the time professor of zoology at Southern Illinois University (Carbondale), had published the Classification of the Animal Kingdom, which utilized the traditional two-kingdom system. Only a year later, Blackwelder wrote a note that justified this decision but also showed qualified support for Copeland's latest (i.e., four-kingdom) scheme (Blackwelder 1964). He accused the "inertia" of his colleagues and the lack of a clear definition for the alternate kingdom(s) as being responsible for the lack of general acceptance of multiple-kingdom schemes. Blackwelder used these arguments, together with student familiarity with the old system, as his excuse for not having adopted a multiple-kingdom system the previous year. ${ }^{19}$

While Blackwelder did not recognize the kingdom Protista in his textbook, he did articulate an important point in his paper: it is through use in textbooks that taxonomic schemes become widely disseminated. In the years immediately preceding Whittaker's 1969 paper, the adoption of a protistan kingdom can be attributed largely to its appearance in three influential texts: in addition to Moore's Treatise on Invertebrate Paleontology (see above), Verne Grant's important work on evolution and genetics, The Origin of Adaptations (1963) and G. Evelyn Hutchinson's classic Treatise on Limnology (1966) recognized the kingdom Protista. Because Hutchinson believed Copeland's 1956 scheme to be too "idiosyncratic," he based his scheme on that of Dougherty (1955). Grant based his scheme on that of Whittaker (1959).

Robert H. Whittaker was a distinguished ${ }^{20}$ ecologist whose approach to the alternate-kingdom debate was strongly influenced by his primary research interest, ecosystems analysis. In his first of three commentaries, he complained that the "kingdom Protoctista seems more a product of taxonomic definitions than a grouping of organisms with coherent meaning or common evolutionary theme"

numerous authors including Heywood and Rothschild (1987). In the most recent case the point was made that it is more appropriate in an evolutionary sense to recognize the plants as a subgroup of their parental taxon rather than the reverse.

19. It is of interest to note that Blackwelder was one of the first to cite biochemical data in support of a multiple-kingdom scheme in which the anucleate and the nucleate organisms were assigned to separate kingdoms. Today most systematists consider the division between the prokaryotes and eukaryotes to be one of the most profound divides in the biological world, if not the single most profound.

20. Note that Whittaker, Grant, Hutchinson, and Margulis (see below) were all elected to membership in the National Academy of Sciences (U.S.A.). 
(1957:536). Whittaker the ecologist pointed out that the four major taxa could be correlated with three ecological types to form three taxonomic units: for the most part, producers are identified with plants, consumers with animals, and (more weakly) reducers and transformers or decomposers with fungi and bacteria. Other life-style and cytological features, such as the presence or absence of a cell wall, may be correlated with the nutritional mode. If one divides the multicellular forms along these nutritional lines to form the kingdoms Plantae, Animalia, and Fungi, then the majority of unicellular forms might be considered true plants, animals, or fungi. Whittaker does not explain what is to be the taxonomic fate of those unicellular forms that still cannot be easily subsumed into one of the three kingdoms.

Another major difficulty with this approach is the apparent taxonomic lumping of fungi and bacteria. Whittaker (1957) admitted that this result is not altogether convincing on evolutionary grounds. Upon further reflection, he decided that a greater (but still secondary) emphasis should be placed on level of organization. In his 1959 paper he identified three levels of organization: anucleate (i.e., the Monera), the eunucleate unicellular organisms, and the multicellular organisms. To reconcile the nutritional and organizational divisions, he proposed the recognition of four kingdoms: the Protista (unicellular organisms, divided into the subkingdoms Monera and Eunucleata), the Plantae, Fungi, and Animalia.

The culmination of Whittaker's taxonomic work - and in effect, perhaps, of the alternate-kingdom debate - was his paper, "New Concepts of Kingdoms of Organisms" (1969). There are several obvious reasons why the paper should have made such a major impact. Whittaker was a prominent scholar whose views were presented in a lead article in Science. Unlike some of the earlier works, including those of Whittaker himself, this paper is a brief but scholarly discussion of the debate that proposes a clear alternative. The expressed purpose of the paper was to compare Copeland's schemes with those of Whittaker, but the actual result was the popular establishment of a five-kingdom system through its adoption by numerous workers in numerous texts. The essential difference between Whittaker's previous work and the 1969 paper is that in the intervening decade Whittaker had decided to raise the Monera from a subkingdom of the Protista to a kingdom in its own right (see Fig. 2).

As Whittaker himself pointed out, there are still problems with the five-kingdom system. First, the division between unicellular and multicellular eukaryotes divides close relatives; for 


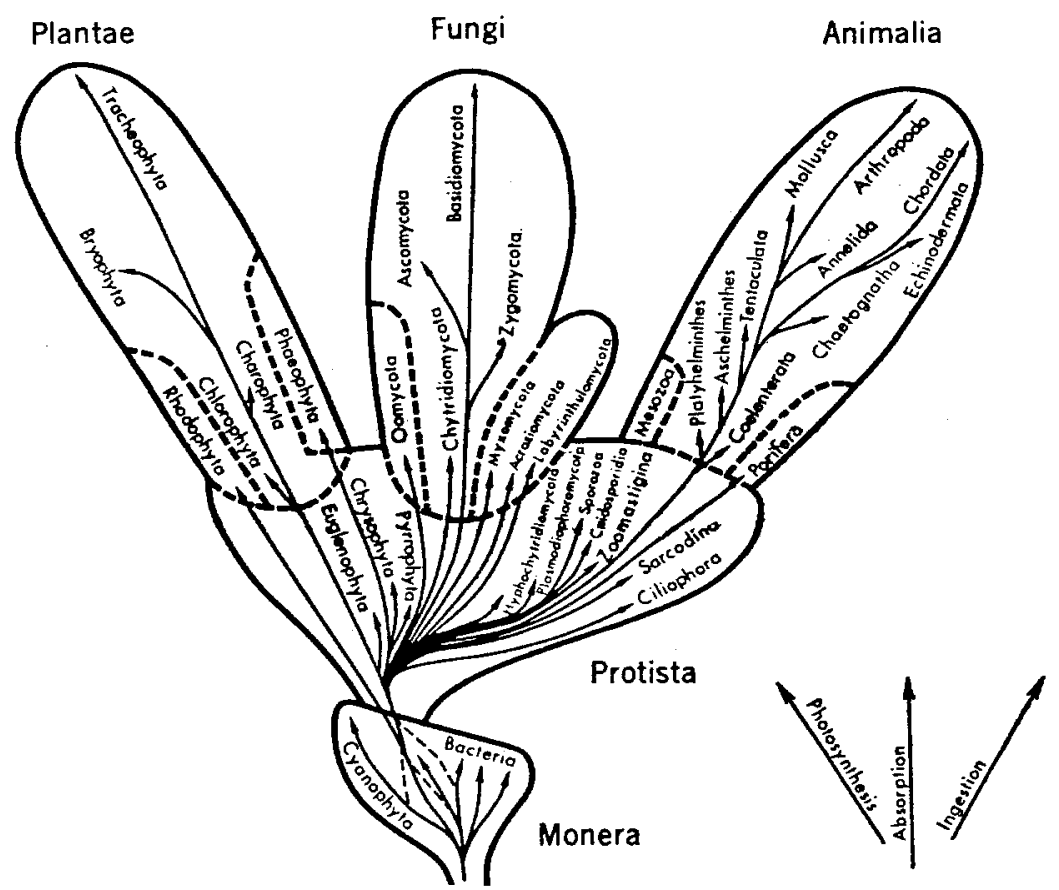

Figure 2. Reproduction of Figure 3 from Whittaker (1969) showing diagrammatically the five-kingdom system of Whittaker. Note the acknowledged polyphyleticism of the three multicellular kingdoms. (Reprinted with permission from Science, 163:150-160, (AAAS.)

example, the phylum Chlorophyta sensu Whittaker includes unicellular green algae, as well as colonial and multicellular forms that gradate so smoothly into the Plantae that any division would be arbitrary. Second, the five-kingdom system creates polyphyletic taxa. Whittaker recognized that because the Rhodophyta (red algae) and Phaeophyta (brown algae) probably arose from different unicellular ancestors than the Chlorophyta, and therefore the rest of the Plantae (see Fig. 2), the Plantae become polyphyletic; he also realized that he was similarly creating polyphyletic taxa in his kingdoms Fungi and Animalia. Third, the kingdom Protista remains a highly diverse group. This is at least partially an artifact of classifying the multicellular kingdoms on the basis of nutrition, while the Protista are defined by their level of organization.

Early support for Whittaker's five-kingdom scheme came from Lynn Margulis (e.g., Margulis 1971, 1974), ${ }^{21}$ although the reaction

21. More recently Margulis has supported Hogg's term "Protoctista" (see above). 
to Whittaker's 1969 proposal was not uniformly enthusiastic (e.g., see Leedale 1974). Yet, the protistan movement has gained enormous momentum in the subsequent years; for example, see John O. Corliss (1986) for a discussion of the latest "protistan revolution." Corliss identifies four reasons for the increasing popularity of the "protist" concept: the separation of the eukaryotes from the prokaryotes, the resurrection of the endosymbiotic explanation for the origin of chloroplasts and mitochondria, improved techniques in such fields as electron microscopy and molecular biology, and improved methodologies for analyzing the rapidly accumulating data. One would like to believe that a fifth reason is a recognition that, as Haeckel himself pointed out, the majority of protists are not related to the "big two," the animals and plants.

\section{WHAT IS TO BE DONE WITH THE UNICELLULAR EUKARYOTES?}

While Corliss, Margulis, and others continue to argue for a kingdom for the unicellular eukaryotes, two new trends have emerged. One is that perpetuated by taxonomists using molecular characteristics such as rRNA sequences. Such studies reveal a fundamental difference between some bacteria - the so-called Archaebacteria - and the rest of the prokaryotes (the "Eubacteria") that is as great as the difference between prokaryotes and eukaryotes (e.g., see Woese 1987). ${ }^{22}$ These workers have proposed erecting three kingdoms for the three taxa; the kingdom Protista presumably suffers a hierarchical demotion.

The other proposal for altering the kingdoms of organisms is concerned more with systematics among the eukaryotes (Heywood and Rothschild 1987; Rothschild and Heywood 1988). We always will be faced with the problem of where the Protista ends and the other eukaryotic kingdoms begin if we continue to treat these other kingdoms as "given." While the majority of protistan groups have never given rise to either animals or plants (which was pointed out as long ago as Haeckel 1892:49), some grade imperceptibly into their descendant kingdom, such as the green algae into the Plantae. Perhaps the only way to effect a final taxonomic reconciliation with evolution would be to subsume the derived eukaryotic kingdoms under their ancestral protistan taxa.

22. Jim Lake, however, supports a different scheme where he segregates Eubacteria, Halobacteria, Methanogens, Eocytes, and Eukaryotes into separate kingdoms, with the first three grouped together in the superkingdom Parkaryotes and the latter two in the superkingdom Karyotes (Lake 1988). The fate of the Protista is not discussed. 
This would, in effect, leave one kingdom for the eukaryotes, the kingdom Protista.

But then what is to be done about the nomenclature of the included taxa? Clearly botanical or zoological suffixes - a lasting legacy of the two-kingdom system - are inappropriate. We have proposed a solution for the largest distinctive monophyletic taxa of eukaryotes - for example, the euglenoids, also known as the euglenophytes and euglenozoa: the widely recognized stem, in this case "eugleno-", is combined with the suffix "-protista" to create the term "euglenoprotista." Other examples of this terminology are cilioprotista (ciliates), chloroprotista (green algae or some phytoflagellates), bacillarioprotista (diatoms), and dinoprotista (dinoflagellates, dinophytes, pyrrhophytes, or dinozoa). The resulting nomenclature is nonprejudicial and easily recognizable.

With this proposal, we have come $180^{\circ}$ from the conventional view of the animal and plant kingdoms in relation to unicellular eukaryotes. Evolution, tradition, and practicality dominate taxonomy at the kingdom levels. The questions now are how best to reconstruct evolutionary history and how best to incorporate this information in a taxonomic scheme that will be practical. And, as always, what is the best nomenclature to express these concepts? So what's in a name? As Juliet eventually learned, quite a bit.

\section{Acknowledgments}

I would like to thank Kay Goodman, Heidi Smith, Andreas Laras, and Elizabeth Leduc, who helped me to overcome a linguistic handicap by translating from German, Greek, and French. George Erickson was more than generous with his manuscript collection. John Corliss and Peter Heywood have supplied both reprints and inspiration. Mostly, I would like to thank Fred Churchill; if he had not prompted my education in the history of biology and invited me to submit this paper, it never would have been written.

\section{REFERENCES}

Agassiz, Louis. 1857. Contributions to the Natural History of the United States of America. Vol. I. Boston: Little, Brown.

Anonymous. 1860. "Science: British Association." Athenaeum, no. 1706, p. 26.

Aristotle. 1941. Historia Animalium. In The Basic Works of Aristotle, ed. Richard Mckeon. New York: Random House.

Blackwelder, R. E. 1964. "The Kingdoms of Living Things." Syst. Zool., 13:74-75. 
British Association for the Advancement of Science. 1861. Report of the Thirtieth Meeting, June-July, 1860. London: John Murray.

Bütschli, Otto. 1880-1882. Protozoa. Abt. I, "Sarkodina und Sporozoa." In Klassen und Ordnung des Thier-Reichs, ed. H. G. Bronn, I, 1-616. Leipzig: C. F. Winter.

Cole, F. J. 1926. History of Protozoology. London: University of London Press.

Copeland, Herbert F. 1938. "The Kingdoms of Organisms." Quart. Rev. Biol., $13: 383-420$.

- 1947. "Progress Report on Basic Classification." Amer. Nat., 81:340-361. 1956. The Classification of Lower Organisms. Palo Alto: Pacific Books.

Corliss, John O. 1978. "A Salute to Fifty-four Great Microscopists of the Past: A Pictorial Footnote to the History of Protozoology. Part I." Trans. Amer. Micros. Soc., 97:419-458.

- 1986. "Progress in Protistology during the First Decade following Reemergence of the Field as a Respectable Interdisciplinary Area in Modern Biological Research." In Progress in Protistology, ed. J. O. Corliss and D. J. Patterson, I, 11-63. Bristol: Biopress.

Darwin, Charles Robert. 1859. On the Origin of Species by means of Natural Selection, or, The Preservation of Favoured Races in the Struggle for Life. 1st ed. London: John Murray.

de Beer, Gavin. 1985. "Owen, Sir Richard." In The Encyclopaedia Britannica 15 th ed., 9:23.

Desmond, Adrian. 1982. Archetypes and Ancestors. Palaeontology in Victorian London 1850-1875. Chicago: University of Chicago Press.

Dobell, C. Clifford. 1911. "The Principles of Protistology." Arch. Protist., 23:269-310.

1932. Antony van Leeuwenhoek and His "Little Animals". New York: Harcourt, Brace.

Dobzhansky, Theodosius; Ayala, Francisco J.; Stebbins, G. Ledyard; and Valentine, James W. 1977. Evolution. San Francisco: W. H. Freeman.

Dougherty, Ellsworth C. 1955. "Comparative Evolution and the Origin of Sexuality." Syst. Zool., 4:145-169, 190.

G. G. 1937. "Hogg, John." Dict. Nat. Biog., 9:997-998.

Grant, Verne. 1963. The Origin of Adaptations. New York: Columbia University Press.

Haeckel, Ernst. 1862. Die Radiolarien. 2 vols. Berlin: I. G. Reimer.

— 1866. Generelle Morphologie der Organismen. Allgemeine Grundzüge der organischen Formen-Wissenschaft, mechanisch begründet durch die von Charles Darwin reformirte Descendenz-Theorie. Vol. II. Berlin: Georg Reimer. 1878. Das Protistenreich. Leipzig: Ernst Günther.

1892. The History of Creation, or, The Development of the Earth and Its Inhabitants by the Action of Natural Causes. 4th ed. Trans. from 8th German ed. by E. Ray Lankester. New York: D. Appleton.

Heywood, Peter, and Rothschild, Lynn J. 1987. "Reconciliation of Evolution and Nomenclature among the Higher Taxa of Protists." Biol. J. Linn. Soc., $30: 91-98$.

Hogg, John 1838. "On the Action of Light upon the Colour of the River Sponge." Abst. Phil. Trans. Roy. Soc. London, $4: 72$.

- 1860. "On the Distinctions of a Plant and an Animal, and on a Fourth Kingdom of Nature." Edinburgh New Phil. J., n.s., 12:216--225.

Hutchinson, G. Evelyn. 1966. A Treatise on Limnology. Vol. II. New York: John Wiley \& Sons. 
Hyman, Libbie Henrietta. 1940. The Invertebrate: Protozoa through Ctenophora. 1st ed. New York: McGraw-Hill.

Kent, W. Saville. 1880-1881. A Manual of the Infusoria: Including a Description of All Known Flagellate, Ciliate, and Tentaculiferous Protozoa, British and Foreign, and an Account of the Organization and Affinities of the Sponges. Vol. I. London: David Bogue.

Kudo, Richard R. 1931. Handbook of Protozoology. Springfield, Ill.: Charles C. Thomas.

- 1966. Protozoology. 6th ed. Springfield, Ill.: Charles C. Thomas.

Lake, James A. 1988. "Origin of the Eukaryotic Nucleus Determined by RateInvariant Analysis of rRNA Sequences." Nature, 331:184-186.

Lamarck, Jean Baptiste. 1984. Zoological Philosophy. An Exposition with Regard to the Natural History of Animals. Trans. Hugh Elliot. Chicago: University of Chicago Press.

Leedale, Gordon F. 1974. "How Many are the Kingdoms of Organisms?" Taxon, 23:261-270.

MacLeod, Roy M. 1965. "Evolutionism and Richard Owen, 1830-1868: An Episode in Darwin's Century." Isis, 56:259-280.

Margulis, Lynn. 1971. "Whittaker's Five Kingdoms of the Organisms: Minor Revisions Suggested by Consideration of the Origin of Mitosis." Evolution, 25:242-245.

1974. "Five-Kingdom Classification and the Origin and Evolution of Cells." Evol. Biol., 7:45-78.

Minchin, E. A. 1912. Introduction to the Study of the Protozoa. London: Edward Arnold.

Moore, Raymond C. 1954. "Kingdom of Organisms Named Protista." J. Paleont, 28:588-598.

Owen, Richard. 1859. "Palaeontology." In The Encyclopaedia Britannica, 8th ed., 17:91-176.

1860. Palaeontology, or, A Systematic Summary of Extinct Animals and Their Geological Relations. Edinburgh: Adam and Charles Black.

1861. Palaeontology, or, A Systematic Summary of Extinct Animals and Their Geological Relations. 2nd ed. Edinburgh: Adam and Charles Black.

Rothmaler, Werner. 1948. "Über das natürliche System der Organismen." Biol. Zentralbl., 67:242-250.

Rothschild, Lynn J., and Heywood, Peter. 1988. "Protistan' Nomenclature: Analysis and Refutation of Some Potential Objections." BioSystems, 21:197202.

Rothschild, Lynn J.; Ragan, Mark A.; Coleman, Annette W.; Heywood, Peter; and Gerbi, Susan A. 1986. "Are rRNA Sequence Comparisons the Rosetta Stone of Phylogenetics?" Cell, 47:640.

Siebold, C. Theodor von. 1845. "Bericht über die Leistungen in der Naturgeschichte der Würmer, Zoophyten und Protozoen während des Jahres 1843 und 1844." Arch. Naturgesch., 11.2:256-296.

Siebold, C. Th. von, and Stannius, H. 1854. Comparative Anatomy. Trans. from 1848 German ed. by Waldo I. Burnett. Boston: Gould and Lincoln.

Smit, P. 1967. "Ernst Haeckel and His "Generelle Morphologie": An Evaluation." Janus, $54: 236-252$.

Stanier, R. Y., and van Niel, C. B. 1941. "The Main Outlines of Bacterial Classification." J. Bacteriol., 42:437-466.

Whittaker, R. H. 1957. "The Kingdoms of the Living World." Ecology, 38:536538. 
1959. "On the Broad Classification of Organisms." Quart. Rev. Biol., 34:210-226.

1969. "New Concepts of Kingdoms of Organisms." Science, 163:150-160.

Williams, Wesley C. 1971. "Owen, Richard.” Dict. Sci. Biog., 10:260-263.

Wilson, Thomas B., and Cassin, John. 1863. "On a Third Kingdom of Organized Beings." Proc. Acad. Nat. Sci. Phila., 15:113-121.

Woese, Carl R. 1987. "Bacterial Evolution." Microbiol. Rev., 51:221-271. 